\title{
OLD BELIEF IN THE MIRROR OF LITERARY WORK
}

The talk of Larisa Soboleva, professor of Ural Federal University, and Olga Zhuravel, associate professor and Dean of the Department of Journalism at Novosibirsk State University and the author of the book entitled Literary Work of Old Believers in the $17^{\text {th }}-$ Early $21^{\text {st }}$ Centuries: Themes, Problems, Poetics concerns the diversity of manuscript sources used and published in the abovementioned book as well as the principles of the Novosibirsk School of Archaeography and Source Studies of which Olga Zhuravel is a representative. The discussion focuses on the problem of genres of the Old Believers' literary work, their utopist ideas, the correlation between folklore and literary traditions paying particular attention to the genre of laments and hagiographic texts whose oral circulation in Old Believers' communities could be encountered as late as the $20^{\text {th }}$ century. The authors talk over the capacity of Old Believers' literary work to reflect the specific features of Russian literature and Russian national mentality. The book under consideration treats all these themes and represents an uncommon phenomenon in the contemporary historiography of the Old Belief and fills significant gaps in our knowledge of the Old Believers' literary work.

Keywords: Old Belief; hagiography; lament; Vyg-Leksa community; Ural and Siberian literature.

Larisa Soboleva [L. S.]The Old-Believers' movement stretches through several centuries of Russian history. It dates back to the mutinous $17^{\text {th }}$ Century; surviving Old Belief communities can still be found in the far corners of Russian and in major population centers such as Moscow and Yekaterinburg. Scientific research on the Old Believers commenced in the $19^{\text {th }}$ century, and has partly shown the same prejudice as the official Orthodox Church. However, mainly due to the works of Kostomarov and Shchapov, the $19^{\text {th }}$ century also saw a significant rethinking of the Old Belief. After their works were published, the Old Belief came to symbolise an unbroken spirit.

A Scientific Renaissance in Old Belief studies occurred during the Soviet period within the scientific school of Novosibirsk State University, the famous Akademgorodok, where the common efforts of the historians and philologists of the Academia and the University brought to light new aspects of the study of the Old Belief. During this period, these new aspects spread across the continent, researchers sought out Old Belief communi- 
ties, books and manuscripts without borders in the Urals, Siberia, the Far East, Altay, Tyva, and Kazakhstan, and combined unique field studies with rigorous scientific systematization and theorizing. Preserving the ancient written tradition had to be combined with an understanding of the contemporary Old-Believers' culture, i.e. turning to the vast variety of sources. The new sources, documents and artifacts, were given an interesting spin while being interpreted within the traditional method of interpretation of the classic Old Belief texts. This trend emerged as the most significant for researchers of the archaeographic department of the Institute of History of the Russian Academy of Sciences led by Academician Nikolay Nikolaevich Pokrovskiy in the 1960s - 1970s.

Close study of the Old Belief has uncovered interesting and unexpected results, connected to the understanding of the phenomenon of schism and preserving tradition - the nexus of ideas, beliefs and practices in which the creative potential of the emerging Russian nation revealed itself. National features show up in the religious sphere, in dogma and everyday culture, in literature and art. These ideas were supported by numerous publications of the new sources from the classical Old Belief heritage, and the modern OldBelievers. The main methodology of the research is based on the hypothesis of the dual nature of the Old-Believers' literacy that combines traditional genre models with folklore poetics. Old-Believers literature appears thereby as unified hypertext, connecting genetically different layers of literacy.

Olga Zhuravel's work, «Литературное творчество старообрядцев XVIII - начала XXI в.: темы, проблемы, поэтика» (Новосибирск, 2012) ["Old-Believers' Literature from the $18^{\text {th }}$ Century to the early $21^{\text {st }}$ Century: Themes, Problems, and Poetics" (Novosibirsk, 2012)], is devoted to the study of the particularities of the Old-Believers' written tradition. We are publishing an extensive interview with the author of the book that, in the opinion of the editors, constitutes a significant event in the contemporary historiography of the Old Belief, as well as filling in many gaps in our knowledge of the Old-Believers' literacy.

Dear Olga, as far as I know, you are familiar with the Old Belief not just in theory - you have taken part in many archaeographic expeditions and had a chance to witness yourself the importance of the literary tradition in the Old-Believers' milieu. When did you first start your research on this topic and what benefits did you experience by being exposed to the living Old Belief tradition?

Olga Zhuravleva [O. Zh.] Dear Larisa, you rightfully mentioned the renaissance in the study of the Old Belief in the scientific school of Academgorodok in Novosibirsk. Indeed, starting from the mid-1960s, under the supervision of Elena Dergacheva-Skop, Elena Romodanovskaya, and Nikolay Pokrovskiy (all of them are my teachers, too), extensive field work was launched, leading ultimately to an event that academics A. M. Panchenko and D. S. Likhachev would coin as 'the archaeographic discov- 
ery of Siberia'. Siberian archaeographers, according to Lihkachev, have not discovered particular authors and manuscript copyists, - they have in fact uncovered the entire Siberian literature, thereby discrediting the prejudiced view of the peasants as illiterate and without intellectual ambition. The works of folk writers that became known recently thanks to this archaeographic research, indeed prove their authors' talents. The Old Belief has survived better beyond the Urals than in the center or in the North of Russia. Fleeing their prosecutors, the Old-Believers took ancient books and manuscripts to the furthest corners of the country. In addition, they created their own works, following the ancient tradition.

I have taken part in many expeditions. Mostly, we were visiting village communities, often lost in unreachable spots, 'in the woods and mountains.' I have the brightest and the dearest impressions from the Old-Believers' skits (solitary or ascetic monasteries) of the upper Yenisei river - life in those places repeats everyday life of the ancient Russian monastery. Starting from my early student years, I had a chance to witness that the Old-Believers are not just the keepers of rare books, but also of the ancient Russian spiritual and everyday traditions. Thus, the ancient books of the pre-Nikon era (before the mid- $17^{\text {th }}$ century) have been put into the context of the atmosphere and beliefs that are practically medieval. I was lucky enough to observe the milieu of the Chasovennye (Chapel) Old-Believers where the unique written tradition of birch bark etchings developed in the $19^{\text {th }}$ and $20^{\text {th }}$ centuries, and still survives today. I was also fortunate to communicate with some of the reallife prototypes of the contemporary Old-Believers' Patericon, created in this community. We have, therefore, found not just the priceless book treasures and contemporary written sources - thanks to the unique experience of the expedition we were able to verify the texts, created by the Old-Believers, and comprehend the ideas, the meaning, and the method from within the Old Belief tradition. In the chapter devoted to the Old-Believers' hagiography, I mention particularly how the Lives of Saints canon, being summarized back in time as a generalization of the real experience (something that V. P. Adrianova-Peretz has written on), influences in turn the lives, the way of thinking, and even the speech patterns of the Old-Believers who have chosen the way of the Christian ascetics - and is moreover found in literature (folk hagiographies of the Old-Believers) with the description of their lives. This is the phenomenon of extraordinary life-making, when there is a close interconnection between someone's life and literature. One priest's wife told us a story of how, listening to the Old-Believers' singing during church holidays since her early childhood, she has imagined life in the skit as a kind of heaven on earth, and how, as a secret runaway, has been preparing herself to be accepted by the 'angelic rank.' Her speech, as well as that of the many hermit Old-Believers of the late $20^{\text {th }}$ century, is full of the speech idioms familiar to the medievalists that study ancient Russian 'Lives.' This speech is the reflection of the topics, of the loci communes of the hagiobiographies, built upon the imitatio angeli (Lives of Ascetics) pattern. This same old lady presented me with a drawing made by her own hand in her youth - the drawing that I used as a cover of my book 
twenty years after our meeting. It depicts a naïve, idealistic Paradise as seen by a young peasant girl. The flowers, the fruit, the animals, and the Saintly Ascetics are united by love and harmony - for a beautiful folk-religious depiction of the Ideal.

That expedition took place long before I began to work on my book. My studies of the ancient Russian literature preceded it. Siberian archaeographers and our Urals and St.Petersburg colleagues who are studying the Old Belief - as well as you, dear Larisa, - belong to the medievalist school. I believe that the application of the method that was developed by classical scholars is of great importance for the successful development of the study of the Old Belief. I have been publishing the ancient Russian sources, ranging from the literary artifacts of the Tobolsk Arch-Bishop House (together with E. K. Romodanovskaya) to the early copies of Stepennaya Kniga (The Book of Ranks) that was the first non-Chronicle historiographic collection, created at the time of Ivan the Terrible (together with N. N. Pokrovskiy, and colleagues from Russia and the USA). My work with the handwriting types of the $16^{\text {th }}$ century then allowed for fluency in Old-Believers' handwriting types, especially the Vygovsky type, that are my specialty. The handwriting types, naturally, are of great importance for the attribution of the authorship, as well as for understanding the ways in which the Old-Believers authors worked with text. As for my book, it grew out of archaeographic findings, and extensive manuscript work that was undertaken by me and my colleagues in the archives and on field trips. Some of the sources are published in the Appendix to my book.

L. S. The generous material included in your book inspires nothing but admiration. The time span is the $18^{\text {th }}$ through the $21^{\text {st }}$ centuries; however, you also touch upon the origins of the Old-Believers' tradition in the $17^{\text {th }}$ century, as well as the early Christian medieval literature tradition. The original source base of the book includes many new manuscript sources that are being made public for the first time. What is your opinion concerning the level and the trends in the study of Old-Believers' literacy, as well as of the place that your work occupies in this context?

O. Zh. My study of the Old-Believers' literature as a spiritual and aesthetic phenomenon became possible mainly due to the well-established tradition of the study of the history and the ideology of the Old Belief, as well as the archaeographic research of colleagues based in Siberia, the Urals and Northern Russia. Their research is constantly widening the source base; new texts that are of both historical and philological interest are being introduced, new Old-Believers writers are being discovered, and our understanding of the scale and the character of the Old-Believers' literature is being transformed.

As concerns the study of the history of the movement and the individual a lot has been done; without the historiographic work of V. G. Druzhinin, P. S. Smirnov, N. N. Pokrovskiy, the pioneering work of N. V. Ponyrko, N. 
S. Guryanova, G. V. Markelov and other Russian scholars, my research would have been impossible. The discovery and study of new sources has helped confirm a number of profound ideas expressed earlier in the works of American Slavists S. A. Zenkovsky and R. Krammy. It seems difficult to overestimate the importance of E. M. Yukhimenko's research, which comprehensively described the history, the culture and the spiritual life of the Vygovsky center. She has discovered and published many works by Vygovsky authors that nevertheless require further philological interpretation.

The appeal to the literary and the aesthetic side of the written heritage of the Old-Believers has been episodic over a long period of time, and there was no research that might describe the Old-Believers' literacy at different stages of its development. The literary heritage of the Vygovsky center seems to be the best studied of all, but the productivity of Vygovsky authors has been so high, and the changes in the creative process so significant that many of the texts have not yet been published, and many issues relating to poetics and artistic peculiarities remain open. Many of those issues require colossal work with manuscript material, and the use of specific hermeneutics, capable of conceptualizing the aesthetic views within which the literary texts were created - in particular, the Baroque.

Archaeographic discoveries of the Russian scholars in the second half of the $20^{\text {th }}$ and the $21^{\text {st }}$ centuries have revealed a large number of Old-Believers' texts, many of them philologically significant. The books and manuscript tradition of Siberia and the Urals region are being extensively studied by historians, such as N. N. Pokrovskiy, N. D. Zolnikova, and scholars based in the Urals, such as your colleagues, R. G. Pihoya, A. T. Shashkov, V. I. Baydin, A. G. Mosin, and others. However, it is a rare case that a philologist is turning to those sources - your own works, Dr. Soboleva, are among the very few where a number of Old-Believers' texts belonging to various genres have been made available to the scientific community, and the historical basis and artistic background have been uncovered for the 'Genealogies' genre. I would like to stress the significance of the recent major publication by the Ural University Press, "A History of the Literature of the Urals" - not just for studies in regional literature, but also for research on the genre system used in the Old-Believers' literature, including hagiography.

Newly discovered Old-Believers' literature need scientific systematization and the establishment of typological and contextual connections. There is an increasing need to identify common trends in the Old-Believers' literature and to assign it its place as a part of Russian literature in general. The researchers have to identify genres that have not lost their relevance in the writings of the Old-Believers throughout the ages, to trace the constant themes, the motifs, and the images which have provided for the longevity of the Old-Believers literary tradition.

The main methodology of the N. N. Pokrovskiy School, to which I have the honor to belong, is interdisciplinary, based on the close cooperation of philologists and historians. Careful handling of the original sources, as well 
as thorough textual research of the manuscripts is conducted taking into account the broad cultural, historical, and philosophical context. These are the principles that I have tried to use in my book.

The focus of the book are the texts that were created in different ideological and artistic paradigms within two main cultural models: the rhetorically oriented literary culture of Vyg (a region in Karelia) and the system based on syncretism of the book and folklore genres, characteristic of the Old-Believers' literature of the $19^{\text {th }}$ and the $20^{\text {th }}$ centuries. What do they have in common? Firstly, these works are associated with early Christian writings and ancient Russian traditions. Vygovsky authors were daring text innovators; they created a new canon that was copying European rhetoric, while simultaneously remaining committed to the Christian literary tradition. Within just a few decades, their work has become a recognized canon.

My own research has revealed the genres that for three centuries have been showing their creative potential: the sermon, book laments, and hagiography. The research highlighted the wide range of fundamental mythologems, upon which the Old-Believers' literature is based and which date back deep into antiquity. The book addresses common literary sources that the authors of the beginning of the $18^{\text {th }}$ and the $20^{\text {th }}$ centuries have based their writings upon. Thus, both Andrei Denisov, and Father Simeon from the Urals skits, the mentor of the Chapel Community (Chasovennoe soglasie) were referencing the same shared circle of "book authorities", including the works of early Christian Neoplatonist, Methodius Lycian (the Olympian), and early Byzantine and Christian mystics and Hesychasts. Old- Believers' literature indeed appeared as a unified, dynamic text space, combining many lines of succession.

L. S. Your monograph comprehensively represents diverse genres of manuscript literature, and it is precisely the combination of philological and historical approaches that enable this work - through the detailed analysis of poetics - to give a valid characterization of the complex and often contradictory Old-Beleivers' world view; it reveals the dynamics of common folk's thoughts on various topics of an ontological character. Can we generally describe the Old-Believers' written tradition as literature - or is it reasonable to treat it, in the manner of $19^{\text {th }}$ century thought, as literacy, given that its main task through the $18^{\text {th }}$ to the $21^{\text {st }}$ centuries was not responding to the aesthetic needs of readers, but upholding of the "Ancient Orthodox" identity?

O. Zh. Indeed, the appearance of works created by the Old Belief writers was justified by various reasons outside the sphere of mere aesthetics: the desire to prove the truthfulness of the doctrine, to refute the position of ideological opponents, and to capture the history of the Consent or to witness the manifestations of the ascetics' holiness. Eschatological issues were very important for the Old Belief writers. However, regardless of pragmatic functions, many texts created for polemic, dogmatic, or commercial 
purposes, have artistic merit and can justifiably be considered not only as narrowly Old-Believers' works, but also as works belonging to Russian literature. When Andrei Rublev was creating his "Trinity", he probably did not consider too much the aesthetic demands of those who would contemplate the icon. Of course, continuing the ancient tradition, the OldBelievers' literature for objective reasons related to the tragic history of the Schism, became an utterly marginalized, albeit large-scale phenomenon. You rightly mentioned, Dr. Soboleva, the attempts to see in it a 'symbol of the unconquered national spirit' and the creativity of the whole Russian nation. I am sure that in the history of Russian literature the brothers Denisov and the most talented peasant Old Belief writers of the $20^{\text {th }}$ century deserve to take their proper place next to Arch-Bishop Avvakum.

Naturally, not all of the written tradition of the Old Belief can be identified as 'literary.' For the monograph, I have selected exclusively those works that carry aesthetic potential. I have no objection to the term 'literacy' (slovesnost'), especially because it is precisely the word, no less 'self-sufficient' ('samovitoe') than rendered by the Futurists; the word's ontological status is the basis of all literary creativity. The term 'literary culture' seems highly relevant as well - I gladly use it, especially in relation to the literary phenomena of the $18^{\text {th }}$ century, when the texts were closely linked to certain types of rhetoric, and were serving not just literary needs.

L. S. Your monograph consists of five chapters, and each of them is devoted to a specific genre of Old Believer literature. However, I think that the Appendix to the book, which contains the newly discovered texts of the manuscript collections owned by the founders of the Vygo-leksinsky community - The Denisov brothers - and one $20^{\text {th }}$ century writer, Afanasiy Murachev, is an integral part of the research. I will have more questions later about the latter personality and work. It seems to me that the referral to the Old Believers' rhetoric of the $18^{\text {th }}$ century, which is considered as the main creative method of the Old-Believers, is justified in the first chapter. For me personally, the connection between the Old-Believers' genre of sermon with the aesthetics of Baroque art, and the polemical tradition of Christian literature, is of great interest. Sermon is at the heart of OldBelievers' literary work, it is present not only in rhetoric, but permeates, for example, narrative genres of historic and hagiographic character. It seems likely that the theoretical understanding of rhetoric peculiar to the Vygoleksinsky school of The Denisov brothers, having constituted a canon, a certain breakthrough to eternity, could have later developed into a system of commonplace and standard expressions. The question is, to what extent did the rhetorical tradition remain creative work over the subsequent development of poetics in the works of Old-Believers?

O. Zh. You are right, Dr. Soboleva, the sermon indeed penetrates all genres of the Old-Believers' written tradition; one can even say that the sermon is 'everything' for the Old Believers. During the first decades of the 
$18^{\text {th }}$ century, in the Vygovsky centre, thanks to the personal energy, work, and most importantly, the extraordinary talent of Andrei Denisov, new genre forms of the sermon developed. All the efforts of the Vygovsky authors were devoted to the creation of a new, effective sermon which would undoubtedly prove the truth of doctrine. Andrei Denisov, dealing with the problems of the pustyn' (hermitage) building, leading the debate, and dealing with urgent everyday problems, finds time to edit the "Great Science of Raymund Lully” («Великая наука Раймунда Люллия», сочинение Андрея Белоботского), and to work on the creation of original Rhetoric, writing sample tropes for theoretical parts of the research, because he fully realizes the importance and effectiveness of the sermon word. We can say that the word itself became a genuine foundation of the Vygovsky center that flourished for nearly half a century. The word of a preacher convinced parishoners in the correctness of the chosen path because it was the only way to salvation. In one of the works that was published in the Appendix to my book, the author Andrei Denisov, using vivid metaphors and generously referring to the Baroque style, celebrates the beauty and majesty of "wise words." Working with Baroque rhetoric enabled the Vygovsky authors to develop a method based on rational principles, the active use of logic and philosophical categories, as well as visual tools. Vyg founders apparently combined this method with personal writer and speaker talents, a combination which resulted in exceptionally high quality sermons and a prolific literary output.

Despite the large number of written texts, by the year 1760 the Vyg creative period ends and the references to folklore change. The best works of the Old-Believers literature of the late period are based on folk tales; they actively involve legend, folklore and mythopoetics as a living source. Afanasiy Murachev, of peasant origin, had lived in chasovenny skit monasteries and learned book culture from the knowledgeable Old Believers. He at the turn of the $20^{\text {th }}$ and the $21^{\text {st }}$ centuries wrote his original compositions, intricately combining literature and folk elements, and vividly expressing his personal relationship with biblical events. He created a sermon-parable about Marfa and Maria, using naive exegesis. He, for example, calls the sister of Lazarus "Mashenka," and invests so much love in describing her sincere faith in Christ that the reader doesn't wince.

In addition to everyday life details, and recreating the 'earthly' context of the parable (for example, a description of the lunch that Marfa was preparing for Christ included 'local open pies' (shanezhki) and 'pies' (pirozhki)), there are the details that deepen psychology and increase the emotionality of the narrative, allowing the reader to visualize the behavior of the characters, even Jesus Christ himself.

The image of Mary in Murachev's text is developed at both symbolic and everyday levels. Mary is the expression of the author's ideal, but also a living, earthly girl, holding superior qualities such as spiritual purity and virginity - these, according to the author, distinguish her from both evangelical forgiven harlot and from Eve. 
"But Mashenka, who was sitting at the feet of Jesus, still a girl, innocent of human sins; although in her virgin (nevestnye) years, but [having] children's righteousness. She's still that beautiful graceful doll, adorned by God's hands and fingers at the creation of Adam and Eve <...>”.

Baroque rhetorical works continue their life in modern times. They are being actively copied, and they affect the Old-Believers' written culture. Exact quotations from the Vygovsky school historical and hagiographic writings were found in the Ural-Siberian Patericon, that was created in the 1980s.

The Appendix contains only a small part of the literature sources that were the basis for my study. Another part was published earlier by me and my colleagues in «Духовная литература староверов востока России XVIII-XX вв.» В 3 т. Новосибирск, 1999 (1 т.); 2005 (2 т.); 2011 (3 т.), some other works are scheduled for publishing.

L.S. The second chapter examines the poetics of the sermon, the leading literary genre for the Old Believers. You trace the line of sermon development from the Baroque parabolic structures of the Vygoleksinsky School to the sermon-parable of the $20^{\text {th }}$ century. The chapter describes in great detail the development of anthropological themes in the Old-Believers' sermon. The monograph repeatedly refers to the theory of human value, characteristic of European humanism. The anthropological method is inherent in modern literary criticism, though, as you remember, the first presentation of the systemic anthropological approach appeared in D. S. Likhachev's work «Человек в литературе Древней Руси» ["Man in the Literature of Ancient Rus"” ] (1956). Is there a fundamental trait in the Old-Believers' anthropology that would characterize the Old-Believers' subculture as having a certain degree of autonomy in describing the nature of humanity, the axiological parameters of one's life's journey, and the survival strategy?

O. Zh. Indeed, I have noticed that the Old Believers were interested in the anthropological problematic at various levels: philosophical, clerical, and phenomenological, especially in the genre of the sermon. The work dedicated to Man by Andrei and Semyon Denisov bizarrely combines logic and the Kabbalah; the meaning is virtuously dug out of the plexus of rhetorical figures; however, in treating the central theme of the composition - Man - the authors (primarily Andrei Denisov) do not question Christian dogma. Through Baroque rhetoric (most importantly, the works of Andrei Belobotsky), the Vygovsky Old Believers entered European cultural and philosophic space. This does not mean, however, that, embracing Aristotle's ideas and the ontological categories of Thomism, the Old Believers forgot their Holy Fathers' traditions and went against Orthodoxy. Quite the opposite, in their dogmatic treatment of the theme, the authors are faithful to the established authorities in the Eastern Orthodox Church. 
"Man is a miraculous, great and beautiful thing, miraculously created by the miraculous God, standing by itself and being in itself, wonderfully composed of the immaterial soul and the material flesh," - writes Andrei Denisov in his sermon. The soul is lighting up the body, and the body is strengthening and beautifying the feelings. The author insists on the unity of the soul and the body, continuing Thomas Aquinas' line in Christian theology. The founder of Catholic theology opposes the ascetic tendency of St. Augustine who, following Plato, insisted on treating the body as the soul's prison. Aquinas suggests the idea of the inseparable unity of the soul and the body and, thus, produces a philosophical apology of the body. The idea of the self-sufficiency of Man comes forward (let us quote Pushkin: "The self-sufficiency of man is the basis for his greatness.")

The Old-Believer author marvels at the wondrous construction of the human body and its organs, its sensations, existing in such wonderful accordance with the soul's life. The whole human essence demonstrates the unity of the mind, the word, and the spirit, because Man is the favorite creation of God. Apologetic ideas are known to have surfaced again in the Renaissance epoch. According to Dante, who anticipated the Humanists, "Of all manifestations of divine wisdom, Man is the greatest wonder." The problem of human dignity and the apology and rehabilitation of his 'nature' is put in the center of Humanist anthropology. Giannozzo Manetti in his treatise "On the Dignity and Excellence of Man" ("De dignitate et excellentia hominis") writes about the beauty, the will and the supremacy of a human being. The Humanist discusses the properties of sight and hearing, the "solemn and divine combination of the parts" of the human body. The Antique formula "human as a thinking animal" finds its bright manifestation in Denisov's work; it stresses not just the mind but also the ability to create and to know everything in the world, including God.

The Humanists developed a Christian view of a man as the ultimate creation; in their works, much as in those of the Apologists, God appears as the supreme artist. Giovanni Pico della Mirandola in "Speech on Human Dignity" ("Oratio de hominis dignitate") puts man in the center of the universe. Man in his work is worth more adoration than the angels because they acquire their supreme spiritual perfection immediately, whilst man has to achieve it by his deeds. This idea is one of the main ones in the works of Andrei and Semyon Denisov. Man unites all the worlds and all levels of being, standing at the crossroads of the universe: "He is the wonderful world of God's creation, and the whole great world manifesting in himself, it can be said, [that he is] the king of creation, and the lord of all creations".

The idea of man as a microcosm originated in ancient philosophy, it was rethought in patristics and then occupied a central place in the writings of the Humanists. In the patristic tradition man was treated not just like another world, and not even so much as a small world, but as a "second world, great in its smallness." When Old Believers addressed this subject, it was out of the need to understand the concept of a person in aesthetic and philosophical categories that were new for them. 
The artistic features of the composition demonstrate the creative approach of the Vygovsky Old Believers of the $18^{\text {th }}$ century to the ideas of European Baroque, putting the Old-Believers' sermon on the same level as the sermons of Simeon Polotsky and Feofan Prokopovich. Almost two centuries later, the Old Believer and ardent polemicist Alexander Miheevich Zapyantsev built his own anthropologic construction. He was head of a community of selfbaptized Old Believers that split from the Spas community at the end of the $19^{\text {th }}$ century, challenging not just the priesthood but also the holy sacraments that were deemed invalid in the world of the Antichrist. The sign of the cross and personal prayer remained the only possibility for salvation for a follower of this community. In his work "What Is Man and What Dignity He Received From God" (1909), Zapyantsev constructs the concept of the human where he proves that man is endowed with all the qualities necessary for salvation from the moment he is created, and that he no longer needs any intermediaries between himself and God. This concept is the cornerstone upon which the whole dogma of the self-baptized Old Believers is founded.

The main arguments of A. M. Zapyantsev are based on citations, taken from authoritative sources, abridged and threaded together by the logic of the author's thought. Essentially, it is a skillful compilation of cited fragments. The author stresses that God the Heavenly Father, Jesus Christ and the Holy Spirit all took part in the creation of man, thus giving him the whole divinity at the moment of his creation. Looking back at Gregory of Nazianzus, he promotes a thought about the initial godliness of man and the reflection of the image of the Holy Trinity in him. The basis for the exegesis of this folk theologian are Apostle Pavel's words that man is God's temple and God's image (1 Kop. 3:16,17) Summarizing the meaning of the quotations, the author writes at the end of his work: "Thus, man is the image of God, the Church of God, and has the Kingdom of God and His Throne in himself". This lapidary conclusion, in the author's opinin, should have justified the whole practice of the self-baptized community that no longer required priests. In his version of "natural theology" Zapyantsev bypasses the dogma of the Fall. Referring to the participation of Jesus Christ in the act of creation, the author does not write of sacrifice in the name of the atonement, and the primordial Adam remains as beautiful and harmonious as ever, in no need in fact of the New Adam. The constructions of the self-baptized ideologist can be typologically compared with the European religious movements of modernity.

The aforementioned Old Belief authors, separated by two centuries, created completely different works. Their composition, their style, their selection and the method of citation differ a lot. Nevertheless, both texts demonstrate a clear tendency towards the apotheosis of man as a creature of God; the dogma of the humiliation of human nature after the Fall in the the Denisov brothers' work is accompanied by jubilant panegyric intonations, while Zapyantsev altogether overlooks this dogma. As noted, both the Denisov brothers and Zapyantsev were members of the two bespopovskoe consents. In this situation, the tendency to accentuate the eminence and greatness of man is 
not accidental, because the type of relationship with God is different: a person has access to a "direct link" with the divine. Quoting G. Florovsky, "in his graceless abandonment, the bespopovets knows that he depends on himself, and must, therefore, be presumptuous <...>" (Флоровский Г. Пути русского богословия [Ways of Russian Theology]. Vilnius, 1991).

I think the idea of personal responsibility is actualized with extraordinary sharpness in the hagiography of the Old Believers, whose eschatological beliefs brought them into conflict with the official church hierarchy and the priesthood. The life of the characters in hagiographic narratives is the way of salvation through union with the community; their survival strategy is primarily a strategy of salvation of the soul and obedience to the will of the Supreme Being, following the path of true faith. This can be seen very well in the "Life" of Korniliy Vygovsky. The complex life course of one of the founders of Vygovsky community was defined by the internal dictates of his soul and by God's will, though it might have looked like a manifestation of passivity for the outside observer. Next to this supreme principle no authority exists; thus Korniliy is able to disobey the order of the patriarch, if it contradicts his inner voice. The Bespopovets Old Believer is left face-to-face with God.

L. S. Let us talk about the special role of Utopia in Old-Believers' views, namely in a Vygovsky preacher of the $18^{\text {th }}$ century, Andrei Denisov. Can one define it as a dominant feature, able to support the viability of the Old Belief movement and to give hope of salvation to the Old-Believers?

O. Zh. Undoubtedly, Georgiy Florenskiy was right to call the Old Belief movement a social apocalypse utopia. The Old-Believers' utopia is based on the actualization of eschatology; it is a part and a manifestation of the mythopoeic consciousness. Naturally, the chapter about the Old-Believers' utopia is at the center of the book - it is also at the center of the Old-believers' mentality. It is not a genre; the utopian text is primarily a world view-related phenomenon, and in our case that world view is religious and eschatologically aligned. This phenomenon is manifested as a complex of motives in literary texts. I am the first researcher who has tried to demonstrate this, because the works containing the Old-Believers' utopian views have been largely overlooked by previous researchers, the works of K.V. Chistov and some notes by S. Zenkovsky being an exception.

L. S. The sources in your book prove, as I think, that the utopian views were rather deep and encompassing for the national worldview. But the Old Believers had their own utopian imagery where idealistic images of the past are combined with eternal harmony. The image of the Church is drawn in accordance with this; due to historical circumstances, the image of the pustyn', the Old-Believers' hermitage, is also a utopia, the only place where salvation of the soul, separated from the world of the Antichrist, becomes possible. The theme of the beautiful pustyn' is conceptualized by the folkChristian tradition in the form of the Garden of Eden in religious poetry, 
lovingly sung in the Old-Believers' milieu until as late as the $20^{\text {th }}$ century; the manuscripts containing spiritual poetry are in abundance in any collection of Old-Believers' manuscripts, such as the Ural University collection. The special role of utopia in Russian folk life not only in the $18^{\text {th }}$, but in all subsequent centuries found its expression in Russian literature. Thus, the Old-Believers' texts relate to the history of Russian national literarature, although they have inimitable genre specifics.

O. Zh. Of course, through the motifs composing the utopian text, as well as through the archetypes underlying them, such as the Holy Land, the motherly source of being, and Sophia (God's wisdom) - that is, through the set of mythologemes, idealizing the past, the Old-Believers' utopia is connected to the national tradition. No research has yet been conducted on works featuring the utopian chronotope; moreover, they were not published for the most part.

L. S. It seems to me that the Old-Believers' utopia can be related more closely to the global quest of mankind, and in your monograph you have made a significant step in this direction. Might it not be appropriate to pay more attention to the contradictions of utopia that dictated a particular type of behavior and lifestyle for the Old Believers who preferred the strategy of passive protest?

O. Zh. Perhaps - however, before conducting a systematic historical and typological study, it was necessary to explore the phenomenon of the OldBelievers' utopia itself. If my assumptions about the proximity of the views of the Old Believers to the ideas of medieval mystics (Joachim of Fiore and Thomas Müntzer) are confirmed and complemented by the broader context, this would be wonderful. As of now, I have uncovered and published sources of various genres, conducted their primary interpretation, and built a model of the Old-Believers' utopian chronotope. Further work will be connected with new archive material.

Just look how thoroughly the image of the world is represented in the sermons of Andrei Denisov! He really is (as R. Krammy rightfully wrote) representing Vyg as an island of salvation in the world of Antichrist. Anyone who is on this island has a very close relationship with the supreme forces, he is under the direct protection of our Heavenly Father, and he feels the protection of, and connection to the dead Old Believers. Denisov constantly insists on the dynamic connection between the earthly and the heavenly worlds. Vyg, like the Holy Land in the ancient Russian world view, is at the center of the world. Vyg inhabitants are referred to as "citizens of Heavenly Jerusalem!" Those are some striking examples of myth creation! The destiny of the the Vygovsky center proves that the effectiveness of the Word!

Later texts - the spiritual poetry and the $19^{\text {th }}-20^{\text {th }}$ centuries ' wailings' prove the vitality of the utopian ideal based on religious symbols along with ancient, pagan archetypes. It is a bright phenomenon of folk Christianity. 
This is the main difference between the folk utopia and the rational utopia of the 'high' literature created by the lay authors, including the classics. The Old-Believers' utopia is rooted in folk mythopoetic consciousness; it is part of mythological thinking.

Yet another task would be to construct a typology of utopia - say, in the culture of the Russian Silver Age. We would probably observe the same constants, the same actualization of eschatological and apocalyptic topics, and the same revival of ancient archetypes. It would not matter if the author in question was Vl. Soloviev, D. Merezhkovskiy or A. Bely: the main breeding ground and a powerful creative resource for utopia is the national 'plot repertoire'.

L. S. An original twist awaits the reader in the fourth chapter, devoted to the genre of literary wailings in Old-Believers' manuscripts. Your monograph discusses in detail the folkloric and Christian origins of this genre and convincingly develops the idea of harmonic synthesis of genetically different techniques in poetics. But it seems to me that the connection of the wailings and the Old Belief principles is not researched thoroughly enough. Thus, for example, this genre was in particular demand with the Bespopovtsy of the Pomorie consent, where the weeping, in fact, stood for the church burial readings, and acquired a ritual function, primarily attributed to folklore. Moving lyrical wailings are so filled with the sensation of the world's tragedy and the transiency of man's being that they can be put alongside Russian 'high' poetry, communicating the borderline existentialist sensations of early modernity. As a reader, I received great aesthetic pleasure from the artistically refined burial wailings of Andrei Denisov and the emotionally moving text of the $20^{\text {th }}$ century Old Believer A. Murachev, "The Weeping of the Holy Mother at the Lord's Cross." The name and the destiny of Murachev, in my opinion, have to be introduced into the History of Russian literature of the $20^{\text {th }}$ century.

O. Zh. In my book, I suggest that the Old-Believers' literary wailings should be seen as a specific genre or, rather, metagenre. I have discovered a broad variety of Old-Believers' compositions that carry on the tradition of the ancient Russian literary wailings. These texts have either been recently made available to scholars, or (in many cases) were published for the first time in my book. The texts are united by the theme of woeful weeping over historical figures (brothers in faith), abstract categories (the church and the holy sacraments), or even Biblical heroes and Christ himself. I have asked myself a question, whether there are persistent features that unite all these texts, except their theme and a certain emotional intention (their tragic or elegiac tonality).

The folk weeping basis of one of the burial 'Words' from Vyg was noted by E. I. Dergacheva-Skop in 1978. She rightfully mentions the closeness of this text to the genre specifics of folk weeping - both appeal to the forces of nature, both woefully complain and address the dead. This has led many to conclude that the wailing poetics combines Vygoleksian rhetoric and folk 
attitude (see: Дергачева-Скоп Е. И. «Сердце болезной сестры убодающ остен...»- рукописный плач середины XVIII в. // Научные библиотеки Сибири и Дальнего Востока. Новосибирск, 1978. Вып.14).

Many of those texts contain rhythmic inclusions, characteristic of folk wailings. Wailing basis is clearly seen even in one question-and-answer composition that carries a strictly pragmatic function. This text, named at the date of its publication "Сочинение о времени, достойном плача» ["А Composition about the Times that are Well Worth Wailing"] is a marvelous example of literary wailing. Reflecting on the fatal date of the Schism, i.e. the split from the true Orthodox faith (in the year 1666), the anonymous author accentuates his sorrow at the loss of church values following the rejection of priesthood - a reality for all the Bespopovtsy Old Believers.

It was important for me to identify the genre-forming features of this text, expressed in the images and the rhythm used. The rhythm of the OldBelievers' wailings has until now been overlooked by researchers - however, the rhythm is a genre-forming feature in the Russian tradition because the collective memory of the folk wailing is embedded in national cultural consciousness. Its rhythm can be recognized in many Old-Believers' texts, even those which are extremely refined and literary, such as the burial 'Words' of Andrei Denisov or Trifon Petrov. The inner need for expressing especially warm feelings towards the Mother of God has caused the prevalence of lyric outset in this Wailing. Both in the author's remarks and the Wailing itself one can observe the widest range of emotions, from love and tenderness to compassion, woe, and even offense and perplexity. These utterly earthly emotions the author assigns to the Mother of God, thus filling in the gaps in the Evangelists' silence about the emotions, and also expressing the quite common and understandable feeling of discontent and sadness at the thought of a Mother not being able to help her Son. The laconism of the New Testament texts is compensated in Eastern Christianity by the church hymns that enter the obligatory liturgy and usually coincide with Passion Week, as well as by the apocrypha ranging from the popular "Passions of Christ" to spiritual poetry.

The 'Wailing' composed by Afanasiy Murachev is undoubtedly original: the Old Believer does not copy any of the known texts. The absence of textual stylistic coincidence between the abovementioned texts and Murachev's composition leads us to believe that the author did not base his text on any specific source, but on some general ideas or common places in the story of the Passions of Christ that had become an oral folk tradition in Orthodoxy.

Thanks to resent archaeographic discoveries, the wailings created in Old-Believers' villages of the Ural and Siberia chasovennye (Chapel Consent) in the $20^{\text {th }}$ and the beginning of the $21^{\text {st }}$ centuries are now being published. The influence of folk genres on those is even stronger.

L. S. In the last chapter of the book you consider the possible development of hagiography in the context of the evolution of this genre. You characterize in detail the $18^{\text {th }}$ century hagiography created by the Old Believers 
of the Pomorie Consent and stress an important feature of its poetics: the inclusion of eschatological ideas and stories into the Lives of Old-Believers' ascetics that prove their confessional exceptionality. Considering that since the $18^{\text {th }}$ century the canonizing of new saints in Russia was significantly restricted and bureaucratized, the presence of the idealized ascetic type within the Old Belief enabled popular sacralization, stemming from a naïve but honest belief in the ability to earn sainthood by devotion to the Old Belief and personal martyrdom. The idea of personal martyrdom as the basis for salvation is even lore central to the Patericon stories of the Old Believers of the Soviet era. I know that this theme was first developed by N. N. Pokrovskiy, and I am glad to see the time when texts about the tragic destinies of the Soviet people are finally coming to light and being studied. In the 1980s, at the time these texts were discovered, there was a feeling that they would be kept indefinitely in some restricted collection.

O. Zh. N. N. Pokrovsky discovered the 'secret' literature of the chasovennye (Chapel) Old Believers, the biggest consent in the Russian East. He described the genre of Genealogy of the consents, as well as a broad circle of texts that demonstrated the continuation of the ancient Russian literature traditions, and the fact that the $17^{\text {th }}-18^{\text {th }}$ century literature traditions were still alive in the Old-Believers' literacy of the Urals and Siberia. In 1990s, N. N. Pokrovsky and N. D. Zolnikova discovered the "Urals and Siberia Patericon" - an ample and unique historical and hagiographic composition, created in the 1940s - 1990s by the chasovennoe consent. At the heart of this collection are compositions of the Old Believers of the $18^{\text {th }}-19^{\text {th }}$ centuries about the history of their consent, the recordings of oral tales and the $\mathrm{Pa}$ tericon collectors' authored texts. The Patericon includes several dozen hagiographic Lives of the settlement inhabitants. It includes a variety of ancient Russian literature and religious folklore genres: the apparition, the miracle, the legend, and the story. Some chapters of the Patericon were published in the First volume of «Духовная литература староверов востока России XVIII-XX вв. » [“The Spiritual Literature of the $18^{\text {th }}-20^{\text {th }}$ centuries of Old Believers of the Russian East"]. At present, two more volumes are scheduled for print; they have been prepared by N. N. Pokrovskiy (the last work by our recently deceased teacher), N. D. Zolnikova, and myself.

My own monograph studies the genre aspects of hagiography in this Patericon, such as stable formulas, motifs, or plot turns, expressed through the system of the traditional Lives topoi. The hagiographical canon is combined here with elements of spontaneous realism, and with the penetration of folk models into text.

It is sometimes hard to draw the line between literature and life, as reflected in the text; between the ambition of the folk hagiographist to "fit" his hero into the literary canon on the one hand, and the reflection of a true situation, reproducing this canon, on the other.

Usage of isolated elements of the genre canon and typization "of hagiographic type" is combined with individualization of a character in the 
Patericon. The Patericon portrays truly original images of the ascetics, and some chapters resemble by genre not so much the Lives as literary biographical portraits. The presence of vernacular expressions, as well as everyday and psychological details, in the Patericon does not allow for the hagiographic canon to be turned into a trivial stencil. The sophisticated powers of observation and the literary talent of the authors have highlighted the most distinctive features of the ascetics' individual paths in the spiritual image of the characters.

The word of the character himself becomes an important means of characterization. One can note here, apart from sensitivity towards the language precision and apt wording, an attempt at veracity, and authenticity. A hero's word can be presented as a citation or a list of his compositions, if the hero is a writer. In the milieu of the chasovennye the Old Believers reader's erudition and literary gift were highly appreciated and considered a kind of asceticism.

L. S. I have to agree that the texts of this Patericon are a bright testimony to the struggle for spiritual independence in the folk environment at the expense of one's own life. The Old Believer ascetics, referring to the images of the first Christians, persecuted by the tyrants, stand head-to-head with the innocent martyrs of the GULAG. Pokrovskiy wrote about this; moreover, this is clear evidence of the creative potential of the folk religious culture, a sort of bonding of times, a consistent devotion to the ideal that in fact lies at the core of the famous 'Russian Idea.'

Summing up our talk, I would like to say in the genre of panegyric that the research presented in your monograph is essential for the understanding of Russian culture as a whole, not just its Old-Believer component. I would like to thank you, dear Olga, for your answers, and to quote an observation from the Conclusion to your book: "At the heart of the OldBelievers' culture and the Old Belief movement itself, there is a striving for the ideal. The vector of the search for moral and social ideals is mainly determined by the eschatological beliefs of the Old Believers. Utopian ideas that were reflected in the folk Christian written tradition of the Old Believers, one way or another have carried through time an ideal image of historic Russia and the folk conceptions of spiritual values."

В беседе профессора Уральского федерального университета Ларисы Соболевой с доцентом, деканом факультета журналистики Новосибирского национального исследовательского университета Ольгой Журавель, автором монографии «Литературное творчество старообрядцев XVIII - начала XXI в.: темы, проблемы, поэтика» (Новосибирск, 2012. 442 с.), обсуждается многообразие рукописных источников, использованных и опубликованных в монографии, выявляются особенности новосибирской школы археографии и 
источниковедения, последователем которой является автор работы. В диалоге затрагиваются проблемы особенностей старообрядческой словесности, утопических воззрений старообрядчества, взаимосвязи письменных и фольклорных традиций. Особое внимание уделяется жанру плачей и житийным текстам, живое бытование которых обнаруживается в старообрядческих скитах вплоть до ХХ в. Обсуждаются выводы, насколько старообрядческая словесность отражает специфические особенности русской литературы и национальной ментальности. Выражается мнение, что данное исследование представляет незаурядное явление в современной историографии староверия и восполняет значительные лакуны в современном знании о старообрядческой словесной культуре.

Ключевые слова: староверие; агиография; плач; выголексинская община; литература Урала и Сибири.

Larisa Soboleva (Лариса Степановна Соболева), prof.

Russia, Yekaterinburg

Ural Federal University

l.s.soboleva@mail.ru

Olga Zhuravel (Ольга Дмитриевна Журавель), dr.

Russia, Novosibirsk

Novosibirsk State University

Olga_zhuravel@mail.ru 